\title{
Nutrient uptake and fruit quality in a nectarine orchard irrigated with treated municipal wastewaters
}

\author{
Gaetano Alessandro Vivaldi ${ }^{\mathrm{a}, *}$, Anna Maria Stellacci ${ }^{\mathrm{b}}$, Carolina Vitti $^{\mathrm{b}}$, Pietro Rubino ${ }^{\mathrm{a}}$ \\ Francisco Pedreroc ${ }^{c}$, Salvatore Camposeo ${ }^{a}$ \\ ${ }^{a}$ Dipartimento di Scienze Agro-Ambientali e Territoriali, Università degli Studi di Bari Aldo Moro, Via Amendola 165/A, 70126 Bari, \\ Italy, Tel./Fax:+39 080.544.2982; emails: gaetano.vivaldi@uniba.it (G.A. Vivaldi), pietro.rubino@uniba.it (P. Rubino), \\ salvatore.camposeo@uniba.it (S.Camposeo) \\ ${ }^{b}$ Consiglio per la Ricerca in agricoltura e l'analisi dell'economia agraria, Unità di Ricerca per i Sistemi Colturali degli Ambienti \\ caldo-aridi, (CREA-SCA), Via Celso Ulpiani 5, 70126 Bari, Italy, Tel. +39-080.5475027; Fax: +39-080.5475023; \\ emails: annamaria.stellacci@crea.gov.it (A.M. Stellacci),carolina.vitti@crea.gov.it (C.Vitti) \\ 'Irrigation Department, Centro de Edafología y Biología Aplicada del Segura (CEBAS-CSIC), Campus Universitario de Espinardo, \\ 30100, Murcia, Spain, Tel. +34-968396303; Fax:+34-968396213; email: fpedrero@cebas.csic.es
}

Received 9 August 2016; Accepted 3 February 2017

\section{A B S T R A C T}

Nowadays, treated municipal wastewater is considered as an alternative water source for irrigation, crucial mainly under dry environments; however, if not well managed, it could negatively affect crops and environment. Four irrigation water sources were tested in order to evaluate their impact in a nectarine orchard: three unconventional wastewaters - including a secondary-treated municipal wastewater (SW), a wastewater made by a simplified lagoon treatment pilot plant (LW), and a tertiary-treated wastewater (TW) - and one conventional freshwater source (FW). Fruit and water chemical composition and fruit quality were evaluated also using a multivariate analysis. The effect on soil chemical fertility was also investigated. As a consequence of various water sources with different nutrient loads, soil nutrient availability, plant uptake and fruit quality were significantly affected by the water source supplied. Plots irrigated with unconventional waters (LW, TW and SW) showed positive impacts on fruit quality (e.g., soluble solids and acidity) and negative nutritional aspects. These results could be attributed to higher soil pH (with lower micronutrients availability) and high concentration of $\mathrm{N}$ and $\mathrm{K}$ in unconventional wastewater sources. The results obtained with principal component analysis suggested us that water, enriched with mineral nutrients, may affect fruit quality; in our study, a lower fruit firmness while higher $\mathrm{h}^{\circ}$ value and total soluble solids of fruits were observed, indicating an earlier ripening. Further studies are needed in order to understand better the long-term effect of municipal wastewater on nectarine orchard.

Keywords: Prunus persica (L.) Batsch; Plant nutritional status; Water-soil-crop interactions; Water recycling; Principal component analysis

\section{Introduction}

By the year 2025, as much as $60 \%$ of the global population may suffer from water scarcity [1]. With about $70 \%$ of the world's freshwater currently used for irrigation, agriculture remains the largest user of water. In some countries,

\footnotetext{
* Corresponding author
}

irrigation accounts for more than $95 \%$ of the developed water supply [2]. In this context, the reuse of treated municipal wastewater (TMW) in agriculture represents one of the most promising ways to reduce irrigation demands in dry water-scarce regions. The major risks that are associated with reclaimed water use for irrigation are: (i) human health concerns stemming from potential food contamination and human infection by pathogens (bacteria, viruses, protozoa, 
helminths), (ii) soil salinization and (iii) accumulation of various nutrients and unknown constituents or contaminants in soil that might adversely affect agricultural production and groundwater quality by migrating to underlying aquifers [3].

In agriculture, management and use of TMW for irrigation require both qualitative and quantitative analysis involving several environmental, agronomic and health-related issues, to ensure the safety and sustainability of water reuse enterprise [4]. Although extensive investigations have been carried out on several aspects of wastewater reuse in agriculture [5-8], many problems related to yield and quality of plant production as well as the effects on plant nutrition have not been studied adequately [9].

Indeed, the long-term use of this water source could create environmental problems and in many cases nutritional imbalances for crops. In fact, TMW includes soluble minerals and dissolved organic matter, which depend quantitatively and qualitatively on the original source of water and on the types and levels of treatment [10]. Often, TMW is somewhat brackish with $\mathrm{Na}, \mathrm{Ca}, \mathrm{Mg}, \mathrm{SO}_{4}, \mathrm{HCO}_{3}$ and $\mathrm{Cl}$ as major ions, but additionally contains plant macronutrients such as nitrogen $(\mathrm{N})$, phosphorous $(\mathrm{P})$ and potassium $(\mathrm{K})[11,12]$ as well as micronutrients. While TMW application can positively affect plant growth by providing additional nutrients [13], excess amounts of salts can adversely affect plant growth and development as a result of their excessive accumulation in the root zone [14]. Moreover, the leaching of excess salts and nutrients below the root zone will increase the potential for groundwater contamination.

Irrigation with TMW may also affect mineral nutrient relations. Plant nutrient availability and uptake by roots is related to several factors: (i) the activity of the nutrient ion in the soil solution, which depends upon $\mathrm{pH}, \mathrm{pE}$, concentration and composition; (ii) the concentration and ratios of accompanying elements that influence the uptake and transport of this nutrient by roots; and (iii) other environmental factors [15]. Multivariate methods and regressive techniques are progressively being used for their effectiveness in several research studies [16,17], also on wastewater reuse application [18]. Principal component analysis (PCA) is a method for multivariate data analysis, first appeared in psychological surveys, which attempt to extract relevant information from various data sets without prior knowledge of classes or sub-groups in the data set. For that reason, in order to understand and interpret the complex interactions occurring in the water-plant system, PCA could be a valuable tool.

Nowadays, high-technology tertiary treatments and disinfection systems, such as activated carbon, reverse osmosis, membrane filtration, chlorination, ozonation, UV irradiation and tertiary lagoons (or maturation ponds), are essential to insure microbial populations remain below critical levels [6]. Although several studies have demonstrated the benefits of using reclaimed water for irrigation of fruit tree including lemon [19], mandarin [20], grapefruit [21], apple [22], peach [23], nectarine [11], olive [24], and coffee [25], this source of water is managed within certain restrictions imposed for environmental protection and for the safeguard of public health [6]. Nevertheless, further studies are needed to understand the effects on a more sensitive species, like nectarine, to avoid nutritional disorders and a deterioration of quantity and quality of fruit yield. For that reason, an investigation of the relationships in the water-soil-crop system was carried out on a multiple source data set collected in a nectarine orchard irrigated with four different water sources. The objectives of this research were firstly to study the effect of different irrigation water qualities sources on soil chemical properties and fruit quality; secondly to understand the effect of the multivariate relationships between water characteristics and fruit composition, by selecting the main variables involved in the process using tools as PCA.

\section{Materials and methods}

\subsection{Experimental orchard and agricultural practices}

The study was carried out during 2012 in a commercial nectarine orchard (Prunus persica L. Batsch.) cv. Big Top grafted on GF 677 rootstock. The grove, located at Trinitapoli (Apulia region, Southern Italy; $41^{\circ} 22^{\prime} \mathrm{N}, 16^{\circ} 03^{\prime} \mathrm{E}, 1 \mathrm{~m}$ a.s.1.), was planted in 2008 at a tree density of 400 trees ha ${ }^{-1}$ with $5.0 \mathrm{~m} \times 5.0 \mathrm{~m}$ spacing. The trees were trained in a vase-shaped configuration. The soil in the orchard was sandy loam (52\% sand, $13 \%$ clay and $35 \%$ silt; USDA textural soil classification), and classified as Vertisol-Gleysols (FAO). The soil chemical characteristics in the top $0.60 \mathrm{~m}$ layer were: $\mathrm{pH}=8.0, \mathrm{EC}_{e}=$

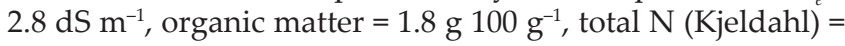
$1.1 \mathrm{~g} \mathrm{~kg}^{-1}$, available $\mathrm{P}=7.6 \mathrm{mg} \mathrm{kg}^{-1}$, exchangeable $\mathrm{K}=0.9 \mathrm{~g} \mathrm{~kg}^{-1}$

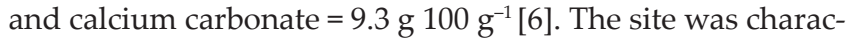
terized by a typical Mediterranean climate, with a long-term (1976-2006) average annual rainfall of $560 \mathrm{~mm}$, two-thirds of which occurred between fall and winter and with an annual maximum and minimum air temperature of $19.3^{\circ} \mathrm{C}$ and $10.0^{\circ} \mathrm{C}$, respectively.

Fertilizers were applied taking into account nectarine nutrient requirements and soil availability $(102,27$ and $0 \mathrm{~kg} \mathrm{ha} \mathrm{h}^{-1}$ of $\mathrm{N}_{2}-\mathrm{P}_{2} \mathrm{O}_{5}-\mathrm{K}_{2} \mathrm{O}$, respectively). In order to avoid overestimates or underestimates of the fertilization value of wastewaters, we did not consider their nutrient supply on the fertilization plan of the orchard but the added nutrients were adequate such that no nutrient deficiencies observed. All the other agricultural practices (pruning, weed and pest control) were followed by the local farmers.

\subsection{Water sources and irrigation management}

Four irrigation water sources were used in the experiment: one conventional water source and three non-conventional wastewater sources. The three wastewater sources consisted of: (i) a secondary TMW (SW), (ii) a wastewater produced from a simplified lagoon treatment pilot plant (LW) and (iii) a tertiary-treated wastewater (TW) made by a membrane filtration public plant located near the experimental site. The conventional water source served as the "control" treatment, which as a freshwater source (FW), supplied from the Marana Capacciotti dam. All these treatments were already described in an earlier paper [6].

The irrigation was managed following the conventional criteria by restoring $100 \%$ of the crop evapotranspiration $\left(\mathrm{mm} ; \mathrm{ET}_{c}\right)$ lost during each irrigation interval. ET ${ }_{c}$ was calculated using FAO recommendations [26]:

$\mathrm{ET}_{\mathrm{c}}=\mathrm{K}_{\mathrm{r}} \mathrm{K}_{\mathrm{c}} \mathrm{ET}_{0}$ 
where $\mathrm{ET}_{0}$ is the Penman-Monteith reference evapotranspiration (mm); $K_{r}$ (reduction coefficient) and $K_{c}$ (crop coefficient) are coefficients used to accurately adjust the $\mathrm{ET}_{0}$ to actual crop evapotraspiration (ET $)$. Specifically, $K_{r}$ remained constant at 0.75 , and $K_{c}$ changed throughout the season from early times (initial), mid season (mid) and late season (end) where respective values were $0.80 \mathrm{~K}_{\text {cinitial }} 1.15 \mathrm{~K}_{\mathrm{cmid}}$ and $0.85 \mathrm{~K}_{\text {cend }}$

Climatic data were supplied by Assocodipuglia (Location: $41^{\circ} 17^{\prime} \mathrm{N}, 16^{\circ} 04^{\prime} \mathrm{E}$ ) (www.agrometeopuglia.it) and recorded at the nearest station only a few kilometers from the experimental site. The water was supplied by drip irrigation with two lines: one on each side of the tree row, and two pressure compensated drippers per tree, each with a flow rate of $12 \mathrm{~L} \mathrm{~h}^{-1}$ that were spaced $1.5 \mathrm{~m}$ apart. The trees were irrigated 3 times per week from May until September. The total amounts of water applied were measured with inline water flow meters, placed in each water treatment line in each of the four replicate blocks. The 2012 seasonal irrigation volume for all treatment was $3,100 \mathrm{~m}^{3} \mathrm{ha}^{-1}$.

\subsubsection{Water quality and soil chemical characteristics}

Water samples were collected biweekly between May and September in order to characterize the irrigation water quality. Four samples from each irrigation source were collected in glass bottles, transported in an ice chest to the lab and stored at $5^{\circ} \mathrm{C}$ before being processed for chemical analyses. Electrical conductivity $\left(\mathrm{EC}_{w}\right)$, ion concentration and $\mathrm{pH}$ were determined on each water sample. The concentrations of anions $\left(\mathrm{PO}_{4}^{3-}, \mathrm{NO}_{3}^{-}, \mathrm{SO}_{4}{ }^{2-}\right)$ and cations $\left(\mathrm{Ca}^{2+}, \mathrm{Mg}^{2+}\right.$, $\mathrm{K}^{+}, \mathrm{NH}_{4}^{+}$) were determined by ion chromatography with a Chromatograph Metrohm (Switzerland), and the sodium absorption ratio (SAR) was computed as $\mathrm{Na}^{+}\left(\mathrm{Ca}^{2+}+\mathrm{Mg}^{2+}\right)^{-1 / 2}$ (molar basis).

At the end of the irrigation season, soil samples were collected at $0-0.20,0.20-0.40$ (data not shown) and $0.40-0.60 \mathrm{~m}$ (data not shown) depths (four samples for each treatment and each depth). The soil $\mathrm{pH}$ was measured on 1:5 soil water extracts and the electrical conductivity $\left(\mathrm{EC}_{e}\right)$ on saturation paste extracts. Organic matter was measured according with Walkley-Black method. The Fe and Mn contents in the soil were measured using the method described by Lindsey and Norwell [27], while $\mathrm{Mg}$, $\mathrm{K}$ and Ca were quantified using the Hendershot and Duquette method [28]. Element concentrations in saturated soil extracted were measured by atomic absorption spectroscopy. Available P and total N were determined using the Olsen and Kjeldahl methods, respectively.

\subsection{Fruit yield, fruit quality and chemical characteristics}

Yield and number of fruits were determined using 12 trees per plot at three commercial harvesting times during July 2012 (9th, 14th and 19th). In each plot, 180 fruits were collected by hand in the middle part of the tree. Fresh weight (g), equatorial diameters $(\mathrm{mm})$, flesh firmness $(\mathrm{F} ; \mathrm{N})$, soluble solids content $\left(\mathrm{SSC} ;{ }^{\circ} \mathrm{Bx}\right.$ ) and titratable acidity $\left(\mathrm{TA} ; \mathrm{mg} \mathrm{L}^{-1}\right)$ were quantified in the laboratory $1 \mathrm{~d}$ after harvest. Flesh firmness was measured with an 8-mm tip penetrometer (Effegi, Milan, Italy) on two peeled surfaces on opposite sides of the equatorial region of the fruit. SSC and TA were measured in juice pressed from the whole fruit: SSC was determined with a hand refractometer (Atago, Tokyo, Japan); TA was determined by titrating $10 \mathrm{~mL}$ of juice with $0.1 \mathrm{~N} \mathrm{NaOH}$ to $\mathrm{pH} 8.1$ and calculating the result as malic acid $\left(\mathrm{mg} \mathrm{L}^{-1}\right)$. A tristimulas CR-200 Chroma meter (Minolta Co., Osaka, Japan) was used to measure the color within the hue angle $\left(\mathrm{h}^{\circ}=\tan ^{-1}\right.$ $\left.\left(b^{*} / a^{*}\right)\right)$ on two surfaces (more and less colored sides) using standard CIE $\mathrm{L}^{*} \mathrm{a}^{*} \mathrm{~b}^{*}$ color space coordinates $(8 \mathrm{~mm}$ viewing aperture diameter, white plate reference, D65 standard CIE illuminant).

Dried fruit tissues were milled into fine pieces (1-2 mm), and $\sim 0.5 \mathrm{~g}$ of each sample was extracted with $1 \mathrm{~mL} 30 \% \mathrm{H}_{2} \mathrm{O}_{2}$ and $9 \mathrm{~mL}$ concentrated $\mathrm{HNO}_{3}$ using microwave-assisted pressure digestion. Total $\mathrm{Cu}, \mathrm{Fe}, \mathrm{Mn}, \mathrm{Zn}, \mathrm{Ca}, \mathrm{K}, \mathrm{Mg}$, $\mathrm{Na}$ and $\mathrm{P}$ were determined on these fruit extracts by inductively coupled plasma-optical emission spectrometry (ICP-OES). On dried fruit tissues, total $\mathrm{N}$ was also quantified through Kjeldahl method.

\subsection{Statistical analysis}

A total of 80 trees were used in this study. The experimental design was a randomized complete blocks design with four experimental plots per block (one per each irrigation water source). The standard plot was made up of 5 trees, located in 4 adjacent rows. The 3 central trees of the middle row were used for measurements, and the other 2 trees were guard trees.

Descriptive statistics were computed to synthesize the main features of data distribution. As most plant and soil parameters showed departure from normality and heteroscedasticity (data not shown), a non-parametric analysis of variance (Kruskal-Wallis test) was performed to evaluate the effects of different water sources, and the Nemenyi-DamicoWolfe-Dunn test was used to assess differences among groups.

\subsubsection{Principal component analysis (PCA)}

PCA uses orthogonal linear transformations to identify a vector in $\mathrm{N}$-dimensional space that accounts for as much of the total variability in a set of $N$ variables as possible-the first principal component $(\mathrm{PC})$ - where the total variability within the data is the sum of the variances of the observed variables, when each variable has been transformed so that it has a mean of zero and a variance of one [29]. A second vector (second PC), orthogonal to the first, is then sought that accounts for as much of the remaining variability as possible in the original variables. Each succeeding PC is linearly uncorrelated to the others and accounts for as much of the remaining variability as possible [30]. Excluding the lower-order PCs, PCA reduces the dimensionality (number of variables) of the data while minimizing the loss of information [31]. In this study, in order to synthesize the information of the multivariate and multisource data, and investigate the relationship between water quality, nutrient uptake and fruit characteristics, PCA was performed. PCA was carried out on the correlation matrix. Variable loadings within each PC and biplots of the selected components were investigated to evaluate the effect of the irrigation treatments on the variables under study. All the analyses were performed using the R 2.15.0 software (R Foundation for Statistical Computing, Vienna, Austria). 


\section{Results}

\subsection{Irrigation water quality and soil effects}

The main chemical parameters of different irrigation water sources are reported in Table 1 . The water quality was different between each source of irrigation water. In general, it was observed that unconventional, treated wastewater sources had significantly higher concentrations of $\mathrm{Na}$ and $\mathrm{Cl}$ than the conventional FW (Table 1). These higher concentrations attributed to higher salinity in the wastewaters where $\mathrm{ECW}$ values were more than twice those of conventional FW. Elevated Na concentrations (120-130 $\left.\mathrm{mg} \mathrm{L}^{-1}\right)$ in TW, LW and SW resulted in a higher SAR (3 on average) although this increase posed little risk regarding soil infiltration problems [32]. The unconventional treated wastewaters also had higher concentrations of some nutrients such as $\mathrm{NO}_{3}^{-}, \mathrm{PO}_{4}^{3-}$, $\mathrm{K}, \mathrm{Ca}$ and $\mathrm{Mg}$ than did FW. As reported in Table 1 nutrients in reclaimed water sources (TW, LW and SW) might have provided high amount of $\mathrm{N}$ and $\mathrm{P}$ and $\mathrm{K}$ fertilization with respect to FW treatment $\left(\mathrm{N}_{2} 101,90\right.$ and 106; $\mathrm{P}_{2} \mathrm{O}_{5} 72,89$ and 75; $\mathrm{K}_{2} \mathrm{O} 85,104$ and 75 for TW, LW and SW, respectively).

Table 1

Irrigation water $\mathrm{pH}$, electrical conductivity $\left(\mathrm{EC}_{w} \mathrm{dS} \mathrm{m}^{-1}\right)$ and chemical compositions ([Na], [Cl], $\left[\mathrm{NO}_{3}\right],\left[\mathrm{PO}_{3}\right]\left[\mathrm{NH}_{4}\right],[\mathrm{K}],[\mathrm{Ca}]$ and $[\mathrm{Mg}], \mathrm{mg} \mathrm{L}^{-1}$ ) for the different irrigation water sources

\begin{tabular}{llccc}
\hline & FW & TW & LW & SW \\
\hline $\mathrm{pH}$ & $7.64 \pm 0.09$ & $7.62 \pm 0.03$ & $7.61 \pm 0.12$ & $7.48 \pm 0.11$ \\
$\mathrm{EC}_{\mathrm{w}}$ & $0.64 \pm 0.00$ & $1.50 \pm 0.03$ & $1.49 \pm 0.04$ & $1.52 \pm 0.03$ \\
$\mathrm{Na}$ & $48.2 \pm 3.35$ & $119.6 \pm 2.36$ & $133.8 \pm 8.92$ & $126.9 \pm 5.90$ \\
$\mathrm{Cl}$ & $49.6 \pm 3.70$ & $161.9 \pm 20.35$ & $199.2 \pm 10.62$ & $180.2 \pm 12.32$ \\
$\mathrm{NO}_{3}$ & $0.89 \pm 0.61$ & $1.50 \pm 0.28$ & $4.34 \pm 2.49$ & $0.17 \pm 0.11$ \\
$\mathrm{PO}_{4}$ & $0.37 \pm 0.37$ & $30.63 \pm 5.39$ & $37.78 \pm 1.90$ & $32.00 \pm 6.46$ \\
$\mathrm{~K}$ & $0.33 \pm 0.33$ & $22.78 \pm 1.15$ & $28.00 \pm 1.91$ & $22.56 \pm 1.73$ \\
$\mathrm{NH}_{4}$ & $1.93 \pm 0.64$ & $41.78 \pm 3.79$ & $36.40 \pm 4.77$ & $44.33 \pm 5.14$ \\
$\mathrm{Ca}$ & $49.6 \pm 6.34$ & $90.33 \pm 7.67$ & $100.00 \pm 11.30$ & $83.11 \pm 3.86$ \\
$\mathrm{Mg}$ & $12.2 \pm 1.08$ & $20.22 \pm 1.24$ & $25.44 \pm 3.22$ & $21.56 \pm 0.44$ \\
\hline
\end{tabular}

Note: $\mathrm{FW}=$ freshwater; $\mathrm{TW}=$ tertiary water; $\mathrm{LW}=$ simplified lagoon water; $\mathrm{SW}=$ secondary water.

Each value represents a mean of nine replications and standard error.
These values were higher compared with those observed in other water sources reused on fruit trees (citrus) under similar Mediterranean climatic conditions [33]. Therefore, once again, it has been demonstrated that reclaimed water use could allow for a significant reduction in fertilizer application and in our case to replace nutrients requirements.

The different irrigation treatments slightly affected soil chemical characteristics (Table 2). Despite higher $\mathrm{EC}_{e}$ values in the non-conventional water sources, no statistical differences were observed in the soil for this parameter. In regard to other soil chemical parameters, significance differences were found on $\mathrm{pH}, \mathrm{P}$ and $\mathrm{Ca}$ between treatments (Table 2). In particular, a significant increase in soil $\mathrm{pH}$ in the plots irrigated with municipal wastewater (TW, LW and SW) was observed with respect to FW $(8.12,7.85,7.98$ vs. 7.69 , respectively). Ca concentration of plots irrigated with TW was slightly lower $\left(3.18 \mathrm{~g} \mathrm{~kg}^{-1}\right)$ with respect to the highest values of plots irrigated with FW (3.35 $\left.\mathrm{g} \mathrm{kg}^{-1}\right)$, LW $\left(3.78 \mathrm{~g} \mathrm{~kg}^{-1}\right)$ and SW $\left(3.40 \mathrm{~g} \mathrm{~kg}^{-1}\right)$. Finally, Olsen P showed the lowest concentrations in plots irrigated with FW and TW (18.52 and $17.7 \mathrm{mg} \mathrm{kg}^{-1}$ with respect to 26.01 and $25.9 \mathrm{mg} \mathrm{kg}^{-1}$ of LW and SW, respectively).

\subsection{Effects on physical, chemical and nutritional fruit quality characteristics}

The main quantitative and qualitative characteristics of fruits are reported in Table 3. Marketable yield and number of fruits per tree were not significantly affected by water quality of various irrigation treatments, unlike the effects on fruit quality. In particular, fruits of trees irrigated with the treated wastewaters with higher salinity (i.e., TW, LW and SW) showed, on average, higher concentrations of soluble solids (SSC) and lower acidity of the extracted fruit juice (i.e., higher $\mathrm{pH}$ ) with respect to FW. TA was lowest for fruits irrigated with LW, whereas SW showed intermediate behavior. Fruits irrigated with LW and SW were characterized by lowest physical characteristics (firmness and diameter). Lower fruit firmness was also found in McIntosh apples irrigated with municipal water [34].

Chemical components of nectarine fruits did not vary considerably among different water sources compared (Table 4). Water quality significantly affected only Ca concentrations with the highest values for FW and lowest for SW.

Table 2

Chemical parameters of soil (0-0.20 m depth) irrigated with different water sources quantified at the end of the irrigation season

\begin{tabular}{|c|c|c|c|c|c|}
\hline Parameters & FW & TW & LW & SW & $p$ value \\
\hline $\mathrm{pH}$ & $7.69 \pm 0.02^{c}$ & $8.12 \pm 0.03^{\mathrm{a}}$ & $7.85 \pm 0.05^{b}$ & $7.98 \pm 0.06^{\mathrm{ab}}$ & $2.2 \mathrm{E}-16$ \\
\hline $\mathrm{EC}_{\mathrm{e}^{\prime}} \mathrm{dS} \mathrm{m}^{-1}$ & $2.98 \pm 0.23$ & $2.51 \pm 0.20$ & $2.71 \pm 0.44$ & $3.35 \pm 0.68$ & n.s. \\
\hline P Olsen, $\mathrm{mg} \mathrm{kg}^{-1}$ & $18.5 \pm 0.76^{\mathrm{b}}$ & $17.7 \pm 2.28^{b}$ & $26.1 \pm 1.03^{\mathrm{a}}$ & $25.9 \pm 0.60^{\mathrm{a}}$ & 0.00010 \\
\hline $\mathrm{K}, \mathrm{g} \mathrm{kg}^{-1}$ & $0.85 \pm 0.02$ & $0.85 \pm 0.03$ & $0.80 \pm 0.02$ & $0.81 \pm 0.03$ & n.s. \\
\hline $\mathrm{Mg}, \mathrm{g} \mathrm{kg}^{-1}$ & $0.36 \pm 0.01$ & $0.33 \pm 0.01$ & $0.33 \pm 0.01$ & $0.32 \pm 0.02$ & n.s. \\
\hline $\mathrm{Ca}, \mathrm{g} \mathrm{kg}^{-1}$ & $3.35 \pm 0.09^{\mathrm{ab}}$ & $3.18 \pm 0.07^{\mathrm{b}}$ & $3.78 \pm 0.07^{\mathrm{a}}$ & $3.40 \pm 0.07^{\mathrm{ab}}$ & 0.02131 \\
\hline $\mathrm{OM}, \mathrm{g} \mathrm{kg}^{-1}$ & $1.79 \pm 0.16^{\mathrm{b}}$ & $1.81 \pm 0.09^{\mathrm{b}}$ & $2.18 \pm 0.03^{\mathrm{a}}$ & $2.09 \pm 0.10^{\mathrm{a}}$ & 0.00045 \\
\hline
\end{tabular}

Note: $\mathrm{FW}$ = freshwater; $\mathrm{TW}$ = tertiary water; $\mathrm{LW}=$ simplified lagoon water; $\mathrm{SW}=$ secondary water; $\mathrm{n} . \mathrm{s}$. = no significant.

Different letters indicate significant differences among treatments at $p \leq 0.05$.

Each value represents a mean of four replications.

Standard error is also reported after the mean value. 
Although it is uncertain, lower fruit Ca may have played a role in lower fruit firmness. The role of $\mathrm{Ca}$ in maintaining cell wall structure and fruit firmness is well known [35].

\subsection{Principal component analysis (PCA)}

Results of PCA carried out on the multivariate and multisource data set composed of the most representative variables of the water and plant system are reported in Table 5 and in Figs. 1 and 2. The first three components (PCs) were able to cumulatively explain about $70 \%$ of total variance and were therefore retained for further analysis. The first PC explained about $32.7 \%$ of total variance, the second $24.2 \%$ and the third $12.7 \%$. The inspection of the loadings of the variables within each component (Table 5) showed that on the first PC the concentrations of most of the nutrients in fruit tissues weighed more and positively, with the highest values for $\mathrm{P}, \mathrm{Mg}, \mathrm{K}$ and $\mathrm{Mn}$. On the second PC, the characteristics of the water sources $\left(\mathrm{EC}_{w^{\prime}} \mathrm{SAR}, \mathrm{NH}_{4}^{+}\right.$and $\mathrm{PO}_{4}{ }^{3-}$ ) together with key fruit quality parameters, flesh firmness and color (negatively) and $\mathrm{pH}$ (positively) showed the highest loadings. Finally, on the third PC, the highest loadings were observed for fruit quality variables, with positive values for fruit weight, diameter, color and firmness while negative values for fruit acidity and SSC. Positive weights were also recorded for $\mathrm{Mg}, \mathrm{Mn}$ and $\mathrm{P}$ fruit concentrations.

The inspection of the biplot of the first two selected components (Fig. 1) showed that the first PC was able to discriminate the observations as a function of fruit maturity, with the fruits of the third harvest being characterized by the highest nutrient concentrations. The second component was able to discriminate the observations as a function of both irrigation water quality (clearly distinguishing conventional from unconventional water treatments) and fruit characteristics thus indicating that water quality markedly affected fruit parameters. Finally, the third component (Fig. 2) distinguished the observations as a function of the fruit quality parameters, highlighting the negative relationship between acidity and SSC on one side and diameter, weight, color and firmness on the other.

Results of PCA thus indicated the strong influence of water quality on fruit characteristics and nutrient uptake.

\section{Discussion}

Although reclaimed water is commonly and successfully used in many countries (e.g., Israel, USA, Australia), in the EU, water reuse, especially in agriculture, faces numerous barriers including human safety and plant toxicity risks. A nectarine orchard was irrigated with conventional and unconventional water to better understand the role of water sources with different qualities (Table 1) on soil and fruit physical, chemical and nutritional characteristics. In regard alkalization, it is well known that $\mathrm{pH}$ of municipal wastewater commonly is weakly alkaline [36]. Furthermore, wastewaters generally contain high concentrations of bicarbonate [37]; thus, application to soils through irrigation can increase soil $\mathrm{pH}$ [38]; in any case in the experimental farm, where the soil was already alkaline $(\mathrm{pH}=8)$, the $\mathrm{pH}$ increase was not shown.

Table 3

Main quantitative and qualitative yield parameters

\begin{tabular}{lllllllll}
\hline Treatments & $\begin{array}{l}\text { Yield } \\
\left(\mathrm{kg} \mathrm{tree}^{-1}\right)\end{array}$ & $\begin{array}{l}\text { Number of } \\
\text { fruits per tree }\end{array}$ & $\begin{array}{l}\text { Soluble } \\
\text { solids }\left({ }^{\circ} \mathrm{Bx}\right)\end{array}$ & $\begin{array}{l}\text { Titratable } \\
\text { Acidity }\left(\mathrm{g} \mathrm{L}^{-1}\right)\end{array}$ & $\mathrm{pH}$ & $\begin{array}{l}\text { Firmness } \\
\left(\mathrm{kg} \mathrm{cm}^{-2}\right)\end{array}$ & $\begin{array}{l}\text { Equatorial } \\
\text { diameter }(\mathrm{mm})\end{array}$ & $\begin{array}{c}\text { Color }\left(\mathrm{h}^{\circ}\right) \\
\text { FW }\end{array}$ \\
\hline $27.70 \pm 2.23$ & $183 \pm 14$ & $18.33 \pm 0.31^{\mathrm{b}}$ & $8.18 \pm 0.18^{\mathrm{a}}$ & $3.77 \pm 0.02^{\mathrm{b}}$ & $5.19 \pm 0.09^{\mathrm{a}}$ & $6.74 \pm 0.03^{\mathrm{d}}$ & $1.16 \pm 0.01^{\mathrm{b}}$ \\
TW & $23.60 \pm 2.10$ & $151 \pm 15$ & $19.80 \pm 0.39^{\mathrm{a}}$ & $7.89 \pm 0.18^{\mathrm{a}}$ & $3.83 \pm 0.02^{\mathrm{ab}}$ & $5.15 \pm 0.10^{\mathrm{a}}$ & $6.65 \pm 0.03^{\mathrm{c}}$ & $1.45 \pm 0.01^{\mathrm{a}}$ \\
LW & $28.19 \pm 2.23$ & $181 \pm 9$ & $19.50 \pm 0.34^{\mathrm{ab}}$ & $7.23 \pm 0.13^{\mathrm{b}}$ & $3.92 \pm 0.02^{\mathrm{a}}$ & $4.65 \pm 0.10^{\mathrm{b}}$ & $6.90 \pm 0.03^{\mathrm{a}}$ & $1.16 \pm 0.01^{\mathrm{b}}$ \\
SW & $28.16 \pm 1.74$ & $177 \pm 10$ & $19.02 \pm 0.37^{\mathrm{ab}}$ & $7.69 \pm 0.17^{\mathrm{ab}}$ & $3.90 \pm 0.03^{\mathrm{a}}$ & $4.72 \pm 0.10^{\mathrm{b}}$ & $6.87 \pm 0.04^{\mathrm{b}}$ & $1.14 \pm 0.01^{\mathrm{b}}$ \\
& n.s. & n.s. & $*$ & $* *$ & $*$ & $* *$ & $*$ & $*$ \\
\hline
\end{tabular}

Note: Values represent average and standard errors.

*Statistically significant at $\mathrm{p}<0.05$ level of significance.

**Statistically significant at $p<0.01$ level of significance.

Table 4

Chemical components of nectarine fruits irrigated with different water sources

\begin{tabular}{llllll}
\hline Parameters & FW & TW & LW & SW & $p$ value \\
\hline $\mathrm{N}, \mathrm{g} \mathrm{kg}^{-1}$ & $12.5 \pm 0.40$ & $13.0 \pm 0.70$ & $13.1 \pm 0.90$ & $12.7 \pm 0.40$ & n.s. \\
$\mathrm{P}, \mathrm{g} \mathrm{kg}^{-1}$ & $1.81 \pm 0.10$ & $1.71 \pm 0.08$ & $1.81 \pm 0.08$ & $1.60 \pm 0.06$ & 0.0651 \\
$\mathrm{~K}, \mathrm{~g} \mathrm{~kg}^{-1}$ & $16.5 \pm 0.69$ & $15.6 \pm 0.52$ & $16.2 \pm 0.63$ & $15.4 \pm 0.42$ & n.s. \\
$\mathrm{Ca}, \mathrm{g} \mathrm{kg}^{-1}$ & $0.58 \pm 0.03^{\mathrm{a}}$ & $0.53 \pm 0.04^{\mathrm{ab}}$ & $0.54 \pm 0.04^{\mathrm{ab}}$ & $0.42 \pm 0.02^{\mathrm{b}}$ & 0.0046 \\
$\mathrm{Mg}, \mathrm{g} \mathrm{kg}^{-1}$ & $0.72 \pm 0.04$ & $0.67 \pm 0.03$ & $0.71 \pm 0.04$ & $0.61 \pm 0.02$ & n.s. \\
$\mathrm{Na}^{\mathrm{g} \mathrm{g} \mathrm{kg}}$ & $0.13 \pm 0.01$ & $0.13 \pm 0.02$ & $0.12 \pm 0.01$ & $0.12 \pm 0.01$ & n.s. \\
\hline
\end{tabular}

Note: FW = freshwater; TW = tertiary water; $\mathrm{LW}=$ simplified lagoon water; $\mathrm{SW}=$ secondary water.

Mean values of the three harvesting times.

Different letters indicate significant differences among treatments at $p \leq 0.05$.

Each value represents a mean of 12 replications.

Standard error is also reported after the mean value. 
Table 5

Weights $(W)$ and loadings $(L)$ of the variables in the three principal components selected (PC1, PC2 and PC3)

\begin{tabular}{|c|c|c|c|c|c|c|c|}
\hline \multirow[t]{2}{*}{ Category } & \multirow[t]{2}{*}{ Parameters } & \multicolumn{2}{|c|}{ PC1 (32.71\%) } & \multicolumn{2}{|c|}{ PC2 $(24.06 \%)$} & \multicolumn{2}{|c|}{ PC3 (12.73\%) } \\
\hline & & $W$ & $L$ & $W$ & $L$ & W & $L$ \\
\hline \multirow[t]{10}{*}{ Fruits } & $\mathrm{Cu}$ & 0.157895 & 0.4235 & -0.182465 & -0.4198 & 0.108247 & 0.1812 \\
\hline & $\mathrm{Fe}$ & 0.284820 & 0.764 & -0.047788 & -0.11 & 0.060052 & 0.1005 \\
\hline & Mn & 0.325582 & 0.8734 & 0.097671 & 0.2246 & 0.195645 & 0.3275 \\
\hline & $\mathrm{Zn}$ & 0.115933 & 0.3109 & -0.147403 & -0.3391 & 0.026298 & 0.04405 \\
\hline & $\mathrm{Ca}$ & 0.285642 & 0.7662 & -0.046771 & -0.1076 & 0.164078 & 0.2746 \\
\hline & K & 0.322619 & 0.8655 & 0.118284 & 0.272 & 0.124701 & 0.2087 \\
\hline & $\mathrm{Mg}$ & 0.325807 & 0.874 & 0.080376 & 0.1848 & 0.204012 & 0.3415 \\
\hline & $\mathrm{Na}$ & 0.306002 & 0.8209 & 0.167156 & 0.3844 & 0.008551 & 0.0143 \\
\hline & $\mathrm{P}$ & 0.315433 & 0.8462 & 0.110135 & 0.2533 & 0.196717 & 0.3292 \\
\hline & $\mathrm{N}$ & 0.233158 & 0.6255 & 0.176555 & 0.4061 & -0.089638 & -0.15 \\
\hline \multirow[t]{5}{*}{ Water } & pH_w & 0.170762 & 0.458 & -0.209246 & -0.4813 & -0.026022 & -0.0435 \\
\hline & EC_w & -0.147044 & -0.3944 & 0.363565 & 0.8364 & 0.106667 & 0.1785 \\
\hline & SAR & -0.150750 & -0.4043 & 0.366598 & 0.8434 & 0.130400 & 0.2183 \\
\hline & $\mathrm{PO}_{4-} \mathrm{W}$ & -0.133694 & -0.3586 & 0.359328 & 0.8267 & 0.148160 & 0.248 \\
\hline & $\mathrm{NH}_{4} \mathrm{w}$ & -0.156772 & -0.4203 & 0.358660 & 0.8251 & 0.078468 & 0.1314 \\
\hline \multirow[t]{7}{*}{ Yield characteristics } & ${ }^{\circ} \mathrm{Bx}$ & -0.106538 & -0.2858 & 0.142365 & 0.3276 & -0.205566 & -0.3441 \\
\hline & Acidity & 0.017754 & 0.04761 & -0.113794 & -0.2618 & -0.365318 & -0.6114 \\
\hline & $\mathrm{pH}$ & -0.024167 & -0.06478 & 0.247391 & 0.5691 & 0.125426 & 0.2099 \\
\hline & Weight & -0.176896 & -0.4745 & -0.089451 & -0.2057 & 0.464671 & 0.7777 \\
\hline & Diameter & -0.165202 & -0.4432 & -0.125430 & -0.2885 & 0.470851 & 0.7881 \\
\hline & Color & -0.171973 & -0.4614 & -0.264436 & -0.6083 & 0.268985 & 0.4502 \\
\hline & Firmness & -0.137163 & -0.368 & -0.288245 & -0.663 & 0.237113 & 0.3969 \\
\hline
\end{tabular}

Note: Highest values are reported in boldface.
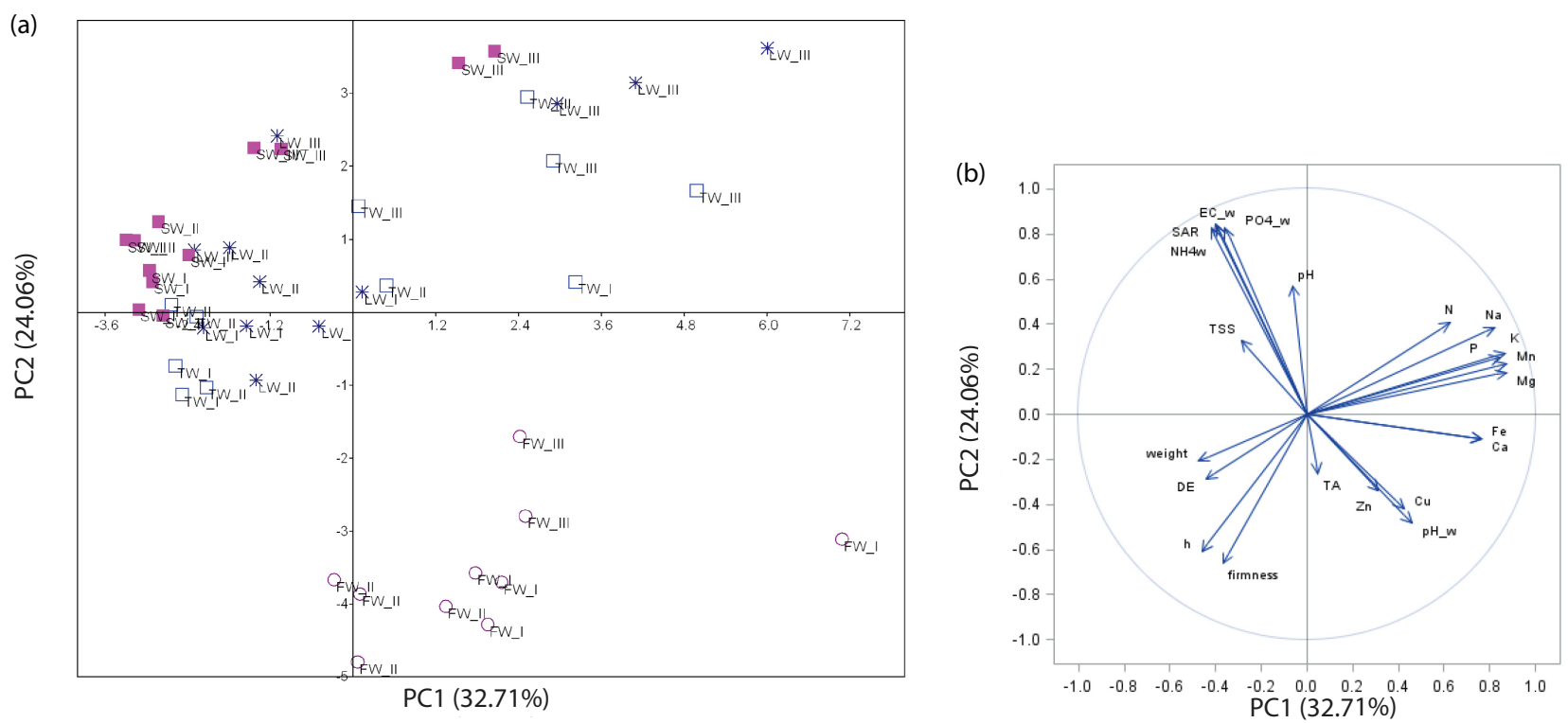

Fig. 1. Plots of the scores (a) and of the variable loadings (b) for the first (PC1,32.71\%) and second (PC2, 24.06\%) components extracted through principal component analysis.

Salinization is the other barrier in agriculture. Salt accumulation in all treatments was above the optimum soil salinity $\left(E_{e}\right)$ threshold of $1.7 \mathrm{dS} \mathrm{m}^{-1}$ proposed for peach by others
[39]. Taking into account the initial measurements, it was possible to conclude that irrigation with reclaimed water did not increase soil salinity in the short term, indeed, as reported in 

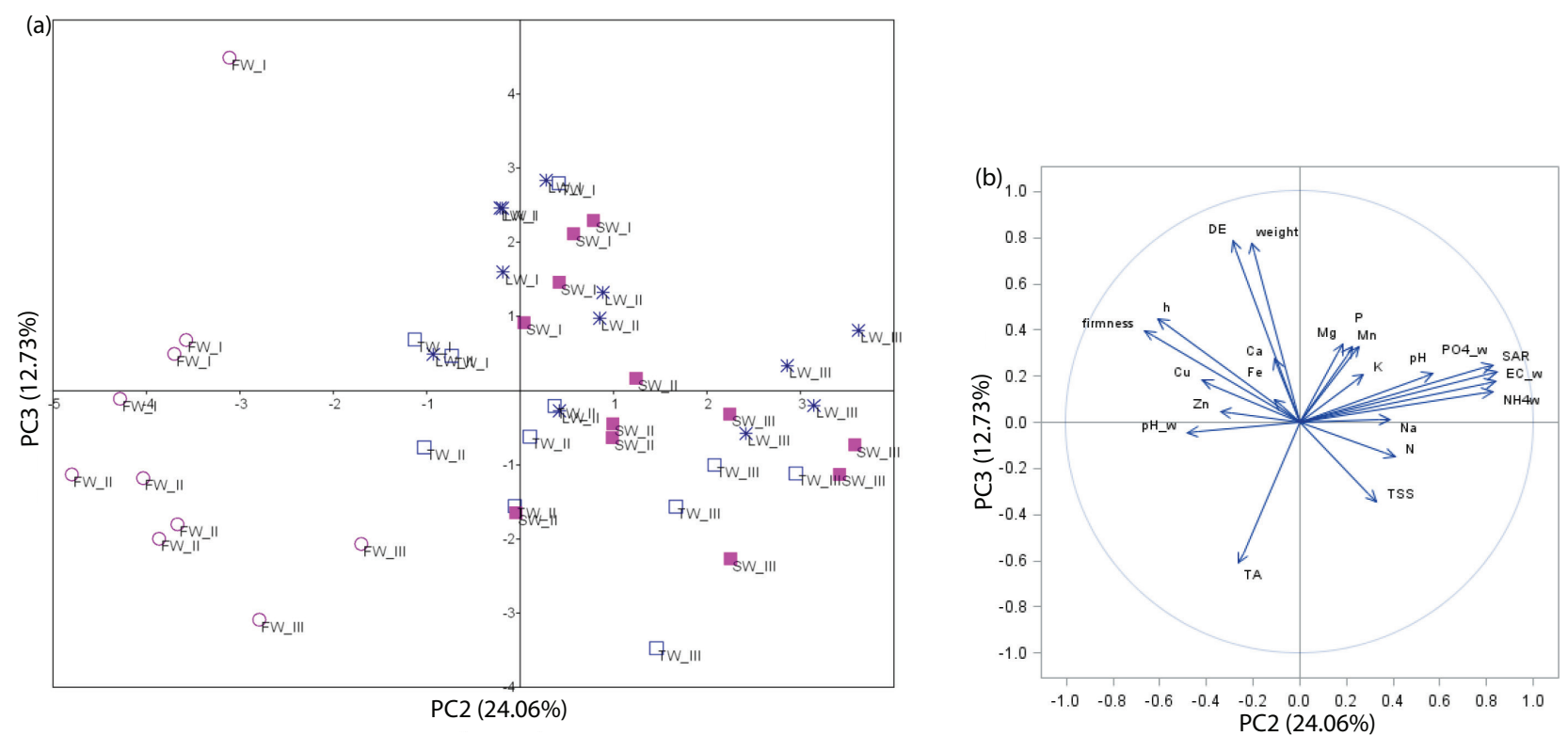

Fig. 2. Plots of the scores (a) and of the variable loadings (b) for the second (PC2, 24.06\%) and third (PC3, 12.73\%) components extracted through principal component analysis.

numerous studies $[12,34,40,41]$, a progressive increase in soil salinity occurs over several consecutive years of irrigation.

In this study the high content of $\mathrm{PO}_{4}^{3-}$ of TW did not increase the $\mathrm{P}$ availability in plots irrigated with this water source, due to the influence of soil $\mathrm{pH}$ on $\mathrm{P}$ fixation and formation of insoluble $\mathrm{Ca}-\mathrm{P}$ minerals. In fact, carbonate mineral surfaces have a marginal rule in the phosphates precipitation, and P removal from soil solution is primarily a solution process and is only secondarily a surface mediated process [42]. Instead, as reported in Table 2, plots irrigated with LW and SW showed an increase of P Olsen probably due to high concentration of organic matter.

In regard to chemical fruit composition, despite the apparently adequate Ca level of soil and the high concentration in the municipal wastewater sources, fruits of trees irrigated with SW showed significantly lower Ca concentration. As reported by others [15], factors that influence the availability of Ca to plants include the total Ca supply, the nature of counterions, substrate $\mathrm{pH}$ and the ratio of $\mathrm{Ca}$ to other cations in the substrate solution. In addition, as the $\mathrm{NH}_{4} / \mathrm{NO}_{3}$ ratio increase, more $\mathrm{Na}$ and $\mathrm{Cl}$ and less $\mathrm{Ca}$ and $\mathrm{K}$ are accumulated in plant tissues. This explains why firmness of fruit irrigated with unconventional treated wastewater showed less firmness. Overall, as observed for $\mathrm{Ca}$, the highest concentrations of $\mathrm{Cu}, \mathrm{Fe}$ and $\mathrm{Zn}$ in fruit tissues were observed in plots irrigated with FW sources, whereas lower values for plots irrigated with municipal wastewater sources (TW, LW and SW) where higher soil pH values were observed. Similarly, the authors observed that tissue Fe and Zn concentrations decreased linearly as root-media $\mathrm{pH}$ increased from 5.0 to 8.5 [43]. This seems to be in accordance with our results. In addition, in saline and sodic soils, the solubility of micronutrients (e.g., $\mathrm{Cu}, \mathrm{Fe}, \mathrm{Mn}$ and $\mathrm{Zn}$ ) is particularly low, and plants grown in these soils often experience deficiencies in these elements [44]. Moreover, low concentrations of $\mathrm{Cu}$ and $\mathrm{Ca}$ in fruits have been associated with fruit softness in trees irrigated with municipal wastewater [34] so lack of firmness in our trees irrigated with unconventional treated wastewater may be related to lower $\mathrm{Ca}$ and $\mathrm{Cu}$ levels. In addition, the high concentration of $\mathrm{N}$ in unconventional treated wastewater, used in this experiment, may have decreased the fruits softness as reported in another study [45] where soil and foliar applications of fertilizers with higher $\mathrm{N}$ content reduced fruit firmness.

Irrigation water sources significantly affected fruit quality and ripening. Overall, fruits of plants irrigated with FW showed lower SSC, pH and diameter, and higher TA and firmness than those irrigated with wastewater thus indicating a slower ripening process. It is well known that increasing the amount of $\mathrm{K}$ fertilization caused a significant increase in the total soluble solids/acid ratio because $\mathrm{K}$ improves sugar transport into the fruits [46,47]. In our experiment, the unconventional treated wastewater sources, with high level of K, improved TSS on fruits. Other studies on peach [23] found that trees exhibited earlier flowering, maturity and ripening from TMW treatments as compared with non-saline controls. It has been demonstrated that fruit quality parameters, such as SSC, increase on treatments irrigated by TMW $[11,21,23,48]$. These authors deduced that salinity could increase the SSC and TA of lemon fruits due to an increase in phenolic content and other organic acids. In this study, although salinity in TMW water treatments was higher than in FW, it was not high enough to directly affect fruit quality parameters such as TA, firmness and size. Further studies are still needed to demonstrate the effect of TMW on such parameters. A substantial reduction in the firmness of fruits of trees in plots irrigated with all unconventional water sources was observed; this result was not corroborated on similar fruit trees species [11].

In this study we used the multivariate analysis with an exploratory purpose, in order to investigate the main relationships existing among water characteristics, fruit 
composition and fruit quality. The results obtained with PCA highlighted the effect of irrigation water types on fruit composition and quality parameters. Specifically, fruits of plants irrigated with FW showed on average higher firmness and $h^{\circ}$ value (as well as higher $\mathrm{Cu}$ and $\mathrm{Zn}$ concentrations), whereas lower total soluble solids, in comparison with fruits irrigated with unconventional treated wastewater (second component). Considering that flesh firmness is the parameter that best segregated fruits maturity level [49], we can support the hypothesis that these results can be indicative of an earlier ripening caused by irrigation with water enriched with mineral nutrients. However, further studies are needed in order to understand better this process.

In addition, PCA highlighted an overall relationship between fruit maturity and tissue element concentrations; this was evident on the first component where fruits of the latest harvest (third) were separated from those of the earlier ones (I and II) and were characterized by the highest nutrient concentrations.

\section{Conclusions}

This experiment highlights how nutrient load, in municipal treated wastewater, can affect the complex water-soilcrop system. Under the experimental conditions investigated, all plots irrigated with unconventional waters showed slightly higher soil $\mathrm{pH}$ but not greater soil salinity $\left(\mathrm{EC}_{e}\right)$. Although high concentration of $\mathrm{PO}_{4}^{3-}$ in unconventional treated wastewater, an increase of available phosphorus was observed only in the soil irrigated with LW and SW.

Fruits irrigated with unconventional treated wastewater showed, regardless of treatments, higher TSS and $h^{\circ}$ value, and lower firmness and TA. As a consequence of different soil nutrient availabilities and uptakes, chemical fruit composition was significantly affected by different water sources supplied. Fruits of trees irrigated with FW showed higher $\mathrm{Ca}$, $\mathrm{Cu}, \mathrm{Fe}$ and $\mathrm{Zn}$ concentrations and slower ripening processes in comparison with those irrigated with unconventional water. PCA was useful to explore the relationships in the complex water-soil-plant data set by downsizing the original data. Only three factors were able to concentrate about $70 \%$ of the information contained in the original 22 variables, and the results underlined the effect of irrigation water sources on fruit composition and quality parameters. Longterm studies are necessary on this crop to get knowledge on leaching requirements and appropriate crop management to avoid salinity and sodicity hazards and soil degradation $[32,50]$. Reuse of TMW for irrigation can be an important ecofriendly strategy; however, a constant monitoring of water characteristics throughout the irrigation season is important to benefit most from their use.

\section{Acknowledgments}

The authors wish to thank the Italian Ministry of University and Research (MIUR) for its financial support under the Project In. T.e.R.R.A. (contract No. 01_01480) co-funded within the Italian Program "PON/Ricerca e Competitività 2007-2013" and from "Fondo di Sviluppo e Coesione" 2007-2013 - APQ Ricerca Regione Puglia "Programma regionale a sostegno della specializzazione intelligente e della sostenibilità sociale ed ambientale FutureInResearch". In addition the authors want to acknowledge Marcello Mastrangelo and Dr. Cosimo Giannotta for their help in chemical analysis and data processing.

\section{References}

[1] D. Pimentel, O. Bailey, P. Kim, E. Mullaney, J. Calabrese, L. Walman, F. Nelson, X. Yao, Will limits of the earth's resources control human numbers? Environ. Dev. Sustain., 1 (1999) 19-39.

[2] FAO, AQUASTAT: Global Information System on Water and Agriculture, 2012. Available at: http://www.fao.org/nr/water/ aquastat/main/index.stm

[3] I.K. Kalavrouziotis, P. Kokkinos, G. Oron, F. Fatone, D. Bolzonella, M. Vatyliotou, D. Fatta-Kassinos, P.H. Koukoulakis, S.P. Varnavas, Current status in wastewater treatment, reuse and research in some Mediterranean countries, Desal. Wat. Treat., 53 (2013) 2015-2030.

[4] A. Hadipoura, T. Rajaeeb, V. Hadipoura, S. Seidiradb, Multi-criteria decision-making model for wastewater reuse application: a case study from Iran, Desal. Wat. Treat., 57 (2015) 13857-13864.

[5] K.T. Morgan, T.A. Wheaton, L.R. Parsons, W.S. Castle, Effects of reclaimed municipal waste water on horticultural characteristics, fruit quality, and soil and leaf mineral concentration of citrus, HortScience, 43 (2008) 459-464.

[6] G.A. Vivaldi, S. Camposeo, P. Rubino, A. Lonigro, Microbial impact of different types of municipal wastewaters used to irrigate nectarines in Southern Italy, Agric. Ecosyst. Environ., 181 (2013) 50-57.

[7] G.A. Vivaldi, S. Camposeo, M.A. Mastro, G. Lacolla, A. Lonigro, P. Rubino, Effect of irrigation with different municipal wastewaters on ripening indexes and chemical components of nectarine fruits, Acta Hortic., 1084 (2015) 401-407.

[8] S.R. Grattan, F.J. Díaz, F. Pedrero, G.A. Vivaldi, Assessing the suitability of saline wastewaters for irrigation of Citrus spp.: emphasis on boron and specific-ion interactions, Agric. Water Manage., 15 (2015) 48-58.

[9] I.K. Kalavrouziotis, P.H. Koukoulakis, Plant nutrition aspects under treated wastewater reuse management, Water Air Soil Pollut., 218 (2011) 445-456.

[10] F. Pedrero, I. Kalavrouziotis, J.J. Alarcon, P. Koukoulakis, T. Asano, Use of treated municipal wastewater in irrigated agriculture-review of some practices is Spain and Greece, Agric. Water Manage., 97 (2010) 1233-1241.

[11] S. Lurie, S. Zilkah, I. David, Z. Lapsker, R.B. Arie, Quality of 'Flamekist' nectarine fruits from on orchard irrigated with reclaimed sewage water, J. Hortic. Sci., 71 (1996) 313-319.

[12] E. Segal, A. Dag, A. Ben-Gal, I. Zipori, R. Erel, S. Suryano, U. Yermiyahu, Olive orchard irrigation with reclaimed wastewater: agronomic and environmental considerations, Agric. Ecosyst. Environ., 140 (2011) 454-461.

[13] E. Weber, S. Grattan, B. Hanson, G.A. Vivaldi, R.D. Meyer, T. Prichard, Recycled water causes no salinity or toxicity issues in Napa vineyards, Calif. Agric., 68 (2014) 59-67.

[14] T.W. Biggs, B. Jiang, Soil salinity and exchangeable cations in a wastewater irrigated area, India, J. Environ. Qual., 38 (2009) 887-896.

[15] S.R. Grattan, C.M. Grieve, Salinity-mineral nutrient relation in horticultural crops, Sci. Hortic., 78 (1999) 127-157.

[16] V. de Paul Obade, R. Lal, A standardized soil quality index for diverse field conditions, Sci. Total Environ., 541 (2016) 424-434.

[17] A.M. Stellacci, A. Castrignanò, A. Troccoli, B. Basso, G. Buttafuoco, Selecting optimal hyperspectral bands to discriminate nitrogen status in durum wheat: a comparison of statistical approaches, Environ. Monit. Assess., 188 (2016) $1-15$.

[18] Y. Elmeddahia, H. Mahmoudib, A. Issaadic, F.A. Mattheus Goosend, Analysis of treated wastewater and feasibility for reuse in irrigation: a case study from Chlef, Algeria, Desal. Wat. Treat., 57 (2015) 5222-5231. 
[19] F. Pedrero, A. Allende, M.I. Gil, J.J. Alarcón, Effects of variations in quality of treated wastewater used in irrigation on soil chemical properties, leaf mineral status and crop production of lemon trees, Agric. Water Manage., 109 (2012) 54-60.

[20] F. Pedrero, J.F. Maestre-Valero, C. Romero-Trigueros, P. Nortes, F. Pedrero, O. Mounzer, J.M. Bayona, J.J. Alarcón, E. Nicolás, Long-term physiological and agronomic responses of mandarin trees to irrigation with saline reclaimed water, Agric. Water Manage., 166 (2015) 1-8.

[21] F. Pedrero, O. Mounzer, E. Nicolás, J.J. Alarcón, Influence of irrigation with saline reclaimed water on young grapefruits, Desal. Wat. Treat., 51 (2012) 2488-2496.

[22] G.M. Neilsen, D.S. Stevenson, J.J. Fitzpatrick, The effect of municipal wastewater irrigation and rate on $\mathrm{N}$ fertilization on petiole composition, yield and quality of Okanagan Riesling grapes, Can. J. Plant Sci., 69 (1989) 1285-1294.

[23] F.M. Basiouny, The use of municipal treated effluent for peach tree irrigation, Proc. Fla. State Hort. Soc., 97 (1984) 345-347.

[24] A.M. Palese, V. Pasquale, G. Celano, G. Figliuolo, S. Masi, C. Xiloyannis, Irrigation of olives groves in Southern Italy with treated municipal wastewater: effects on microbiological quality of soils and fruits, Agric. Ecosyst. Environ., 129 (2009) $43-51$.

[25] U. Herpin, T.V. Gloaguen, A.F. da Fonseca, Montes, C.R. Mendonc, F.C. Piveli, R.P. Breulmann, G. Forti, A.J. Melfi, Chemical effects on the soil-plant system in a secondary treated wastewater irrigated coffee plantation - a pilot field study in Brazil, Agric. Water Manage., 89 (2007) 105-115.

[26] R.G.Allen, L.S. Pereira, D. Raes, M.Smith, Crop Evapotranspiration - Guidelines for Computing Crop Water Requirements, FAO Irrigation and Drainage Paper No. 56, 1998, p. 15.

[27] W.L. Lindsey, M.A. Norwell, A new DPTA-TEA soil test for zinc and iron, Agron. Abstr., 61 (1969) 84-90.

[28] W.H. Hendershot, M. Duquette, A simple barium chloride method for determining cation exchange capacity and exchangeable cations, Soil Sci. Soc. Am. J., 50 (1986) 605-608.

[29] N. O'Rourke, L. Hatcher, A Step-by-Step Approach to Using $\mathrm{SAS}^{\circledast}$ for Factor Analysis and Structural Equation Modeling, SAS Institute Inc., Cary, NC, 1997.

[30] L.I.Smith, A Tutorial on Principal Component Analysis, Vol.2012, 2002. http://faculty.iiit.ac.in/mkrishna/PrincipalComponents. pdf. Accessed 8 Oct 2016.

[31] I.T. Jolliffe, Principal Component Analysis, 2nd ed., Springer, New York, 2002.

[32] R.S. Ayers, D.W. Westcot, Water Quality for Agriculture, FAO Irrigation and Drainage, Rome, 1985, p. 174.

[33] F.Pedrero, J.F. Maestre-Valero, O. Mounzer,J.J. Alarcón, E. Nicolás, Physiological and agronomic mandarin trees performance under saline reclaimed water combined with regulated deficit irrigation, Agric. Water Manage., 146 (2014) 228-237.

[34] M. Meheriuk, G.H. Neilsen, Fruit quality of McIntosh apples irrigated with well or municipal waste water, Can. J. Plant Sci., 71 (1991) 1267-1269.

[35] C.H. Crisosto, K.R. Day, R.S. Johnson, D. Garner, Influence of in-season foliar calcium sprays on fruit quality and surface discoloration incidence of peaches and nectarines, J. Am. Pomol. Soc., 54 (2000) 118-122.
[36] M.M. Rusan, S. Hinnawi, L. Rousan, Long term effect of wastewater irrigation of forage crops on soil and plant quality parameters, Desalination, 215 (2007) 143-152.

[37] A. Kumar, E. Christen, Developing a Systematic Approach to Winery Wastewater Management, Report CSL05/02, Final Report to Grape and Wine Research \& Development Corporation, CSIRO Land and Water Science Report, Adelaide, 2009.

[38] D.L. Suarez, J.D. Wood, S.M. Lesch, Effect of SAR on water infiltration under a sequential rain-irrigation management system, Agric. Water Manage., 86 (2006) 150-164.

[39] E.V. Maas, S.R. Grattan, Crop Yields as Affected by Salinity, R.W. Skaggs, J. van Schilfgaarde, Eds., Agricultural Drainage, Agron Monograph 38, ASA, CSSA, SSSA, Madison, 1999, pp. 55-108.

[40] S. Toze, Reuse of effluent water-benefits and risks, Agric. Water Manage., 80 (2006) 147-159.

[41] S. Laurenson, N. Bolan, E. Smith, M. Mccarthy, Review: use of recycled wastewater for irrigating grapevines, Aust. J. Grape Wine Res., 18 (2011) 1-10.

[42] S. Tunesi, V. Poggi, C. Gessa, Phosphate adsorption and precipitation in calcareous soils: the role of calcium ions in solution and carbonate minerals, Nutr. Cycl. Agroecosyst., 53 (1999) 219-227.

[43] J.A. Biernbaum, W.R. Argo, Effect of root-media $\mathrm{pH}$ on impatiens shoot micronutrient concentrations, HortScience, 30 (1995) 858.

[44] A.L. Page, A.C. Chang, D.C. Adriano, Deficiencies and Toxicities of Trace Elements, K.K. Tanji, Ed., Agricultural Salinity Assessment and Management, 1990, pp. 138-160.

[45] A.D. Hernández-Fuentes, M.T.L. Colinas, J.F. Cortes, C.V. Saucedo, Sánchez and Alcázar J.R., Effect of Fertilization and Storage Conditions on Postharvest Quality of Zacatecas-Type Peach (Prunus persica (L.) Batsch), Acta Hortic., 549 (2002) 507-515.

[46] E. Abd El-Razek, D. Treutter, M.M.S. Saleh, M. El-Shammaa, A. Amera, N. Abdel-Hamid, Effect of nitrogen and potassium fertilization on productivity and fruit quality of "crimson seedless" grape, Agric. Biol. J. North Am., 2 (2011) 330-340.

[47] P. Martin, R. Relgado, M.R. González, J.I. Gallegos, Colour of 'Tempranillo' grapes as affected by different nitrogen and potassium fertilization rates, Acta Hortic., 652 (2004) 153-159.

[48] C.B. Ahmed, B.B. Rouina, S. Sensoy, M. Boukhriss, Saline water irrigation effects on fruit development, quality, and phenolic composition of virgin olive oils, Cv. Chemlali, J. Agric. Food Chem., 57 (2009) 2803-2811.

[49] R. Infante, D. Aros, L. Contador, P. Rubio, Does the maturity at harvest affect quality and sensory attributes of peaches and nectarines? N. Z. J. Crop Hortic. Sci., 40 (2012) 103-113.

[50] S. Bedbabis, D. Trigui, C. Ben Ahmed, M.L. Clodoveo, S. Camposeo, G.A. Vivaldi, B. Ben Rouina, Long-terms effects of irrigation with treated municipal wastewater on soil, yield and olive oil quality, Agric. Water Manage., 160 (2015) 14-21. 